International Journal of Child, Youth and Family Studies (2015) 6(4): 539-560

\title{
EXPLORING THE ROLE OF AGENCY ACCREDITATION IN SHAPING SERVICES FOR STREET-INVOLVED YOUTH
}

\author{
Alexandra Fleurie Hunter
}

\begin{abstract}
Over the past decade, the social/human services sector across North America has continually moved towards a strong emphasis on new management systems and tools for performance measurement, as a means to track government investment and to inform services planning. This trend has contributed to the growth of a parallel industry in the form of independent accreditation bodies, which act to develop regulatory standards, as well as to perform evaluations and monitoring. In many communities accreditation now plays a significant role in defining both the eligibility of agencies to apply for government contracts, as well as the performance objectives of organizational management and service delivery. This paper looks at the service system for street-involved youth in Vancouver, Canada, as a site to explore this novel institutional arrangement. Drawing from broader literature on regulatory standards institutions, this paper outlines a research agenda to question the role of accreditation bodies in shaping child and youth care services, as well as the broader values, ideologies, and power dynamics that surround accreditation.
\end{abstract}

Keywords: street-involved youth, homelessness, accreditation, service delivery, private accreditation bodies, standardization

Alexandra Fleurie Hunter is a graduate student in the Faculty of Environmental Studies at York University, HNES 137 - 4700 Keele Street, Toronto, Ontario, Canada, M3J 1P3. E-mail: fleurie.hunter@gmail.com 
International Journal of Child, Youth and Family Studies (2015) 6(4): 539-560

This paper is exploratory in nature. It seeks to expose, and begin to investigate, a significant gap in research related to the planning and delivery of services for streetinvolved youth. In North America, organizational management and program evaluation in the social and human services sector have been an area of interest since the 1970s. However from the late 1990s onwards, the focus on adopting management practices modeled after the business sector has grown substantially, as both service providers and funders look to track investment, produce tangible results, and demonstrate value and accountability. In the context of street-youth services, this has been part of a wider effort to develop more strategic and coordinated service delivery systems (Hambrick \& Rog, 2000; Rosenheck et al., 2001; Concodora, 2008; Wiig \& Tuell, 2008; Social Planning and Research Council of Hamilton, 2009). While many of theses initiatives have led to significant service improvements (see Basi, Clelland, Khind, \& Severinson, 2012, pp. 31-34), they have also led to major changes to service delivery, to organizations, and to the practices and objectives that frame policy and funding (see Guenther, 2011). Therefore as researchers and community advocates strive to engage the actors, resources, and public support necessary to building effective solutions to youth homelessness (see Gaetz, 2014), an accurate understanding of the factors that shape the service system is vital.

These new management trends have also contributed to the emergence of a related industry in the form of private accreditation bodies, which develop performance standards and carry out evaluations and monitoring. Across North America accreditation now often plays a significant role in defining both the eligibility of agencies to apply for government contracts, as well as management and service delivery practices. While there is a relatively expansive body of research on street-youth services, the role of accreditation in shaping policy and service systems - as well as the private institutions that administer accreditation - is an area of research almost entirely unexplored.

This paper looks at Vancouver, Canada as a site to examine the role of private accreditation in shaping services for street-involved youth in a local setting. In the context of Vancouver, accreditation requirements have been formalized into the contract policies of the provincial Ministry of Children and Family Development (MCFD) since 1999. While much of the research and policy discussion on street-youth services in Vancouver is focused on interventions at the municipal or urban-regional level (e.g., Millar, 2009; Basi et al., 2012), funding decisions by the MCFD - which is considered the largest funder of street-youth services in Vancouver (Guenther, 2011, pp. 71-72) play a substantial role in shaping the service system.

The increasing influence of private accreditation in street-youth services, and the social/human services sector more broadly, reveals the need for an expanded perspective on how planning and policy decisions are made, and the actors and institutions involved. Through a focus on governance - meaning "the mechanisms, processes and institutions through which citizens and groups articulate their interests, exercise their legal rights, meet their obligations and mediate their differences” (United Nations Development 
International Journal of Child, Youth and Family Studies (2015) 6(4): 539-560

Programme, as cited in Brunet-Jailly \& Martin, 2010, p. 9) - this paper draws from the literature on accreditation, policy trends in public management, and transnational private regulatory standards institutions, in order to formulate a research agenda on the role of private accreditation in shaping the service system for street-involved youth.

\section{Street-involved Youth and the Service System}

The term "street-involved youth" is often used interchangeably with other terms such as "homeless youth”, “street youth”, “at-risk youth”, or "vulnerable youth”, each of which are commonly used to describe young people who are homeless (Gaetz, 2009). In general, homelessness is understood as people who sleep on the street. However homelessness can best be understood as a continuum, ranging from "absolute" homelessness, whereby people "do not have access to safe and affordable housing and may be living on the street or using temporary emergency shelters" to "relative" homelessness, where housing may be unsafe, unsuitable, unaffordable, or insecure (Condon \& Newton, as cited in Millar, 2009, p. 7). Youth also experience homelessness in unique ways, and encompasses a broad range of conditions, experiences, and backgrounds - from youth who are living on the streets, to youth who have unstable or overcrowded accommodations, or are at risk of homelessness through instability of relationships or income (see Toro, Lesperance, \& Braciszewski, 2011; and Gaetz, O’Grady, Buccieri, Krabanow, \& Marsolais, 2013, pp. 7-8).

Debate exists regarding the nuances of the various terms listed above (see Guenther, 2011), as well as an important critique regarding the harmful effects on youth identity and unequal power dynamics involved in certain labels and descriptions (see Madison, 2000; and Lindell, 2012). While this larger discussion remains outside the scope of this paper, the choice of terminology was intentionally considered. "Streetinvolved youth" appears as a common and consistent choice of language by community agencies and service providers, as well as in academic literature related to this topic. While I would prefer to avoid expressions that impose a characterization on service users, the term "street-involved youth" serves a practical purpose, and also serves as a link to research that frames this article. I therefore adopt the definition of street-involved youth employed by Guenther (2011): “youth and young people up to 24 years of age who do not have a permanent place of their own and are living on the street or are involved in street life to a significant extent” (p. 15).

The concept of the "service system" was also deliberately selected for the purpose of this paper. There are certain important distinctions to be considered, specifically in distinguishing between a "service system" and "homelessness services". As described by De Jong (2013), "a homeless service provider...should be focused on ending each individual's or family's homelessness first and foremost”. Therefore, while the service system for street-involved (or homeless) youth incorporates a continuum of supports and prevention services including street outreach, counseling and mental health services, drop-in centers, hot meal programs, employment and educational supports, these programs should not be equated directly with homelessness service providers. The service system framing also fits into how homelessness intervention is discussed in 
International Journal of Child, Youth and Family Studies (2015) 6(4): 539-560

Vancouver, as a “continuum of housing and support” (Greater Vancouver Regional Steering Committee on Homelessness, 2003), and "refers to organizations in Vancouver which have staff and resources designated to work with street youth" (Guenther, 2011, p. 15).

Based on the reasons described above, the "service system for street-involved youth" has been established as the most clear and appropriate terminology for the scope of this research. Lastly, for the purpose of this paper, consideration of the various service providers involved in street-youth services will serve two purposes. First, as service providers often participate in consultations and decision-making processes, they will be considered as actors involved in governance and policy-making processes. Second, they will be also be considered in the aggregate - "the service system" - as changes to the composition of service providers in the system are an outcome, or product of policymaking processes.

\section{The MCFD and the Service System for Street-involved Youth in Vancouver}

The service system for street-involved youth in Vancouver is highly complex, and has evolved significantly over time. Through the interaction of broad social, political, and economic processes as well as local dynamics, "many significant changes have manifested themselves in the sector...policy and legislative changes...various restructuring and contracting out processes, funding changes and centralization and decentralization movements” (Guenther, 2011, p. 40). As described by Guenther (2011), the governance of street-youth services in Vancouver falls under the jurisdiction of numerous government departments and ministries: "the Ministry of Children and Family Development (MCFD), health/mental health, the School Board, Probations/Corrections .... and you also have a dynamic whereby the three layers of government (City, Federal and Provincial) are fighting around who has which mandate", and the "right" approach to policy-making (pp. 71-72). Private actors also have a role through grant-making and private fundraising. However based on the description below, the MCFD is considered to be one of the most important stakeholders, and is presumed to be the largest funder of street youth services in Vancouver (Guenther, 2011).

Prior to the 1980s the availability of services for street-involved youth in Vancouver was quite limited. The service system was composed primarily of small charities and faith-based organizations, with the province directly providing various social welfare services (Guenther, 2011). In the early 1980s, Vancouver’s street-youth services began a period of significant expansion, coinciding with broader political trends of welfare state reform (Geiger \& Wolch, 1986; Skinner \& Rosenberg, 2005). The provincial government moved to contract out many social service functions to the nonprofit sector and, aside from child welfare/protection and income assistance, "privatization was declared a major policy direction for government in social services" (Callahan \& McNiven, as cited in Guenther, 2011, p. 45). Guenther (2011) describes an overall growth in resources and support for street-youth services during this period, paired with a decentralization of service delivery through a growing non-profit sector of service providers. 
International Journal of Child, Youth and Family Studies (2015) 6(4): 539-560

This expansion of the non-profit sector as the delivery system for street-youth services continued through the 1990s. However, during this period the composition of the service system changed somewhat, as the province began to implement specific funding requirements that favored larger, more business-oriented organizations. By the early 2000s this transformation began in earnest. Described by some as "the corporate makeover of the non-profit sector” (Guenther, 2011, p. 59), large-scale funding cuts at the provincial level incited an overall restructuring of services funded by the provincial MCFD. This included the consolidation of contracts, which resulted in the closure of many small community-based agencies, as well as the introduction of for-profit service providers, including a major contract in Vancouver for one of the four "youth services hubs” established in 2003/2004 (see Miller, 1998; Guenther, 2011). As it currently stands, the service system in Vancouver is dominated by several large organizations (both for-profit and non-profit) that deliver the majority of services, with a limited array of small agencies generally operating through more precarious funding arrangements such as grants and corporate or individual fundraising.

In Vancouver, as in many urban centers across North America, there is growing pressure to develop more strategic coordination and long-term planning across the services system, to not only provide services for homeless and street-involved youth, but to achieve tangible results in decreasing, if not ending, homelessness. Over the past decade, novel governance arrangements have emerged in the metropolitan Vancouver region that include representatives from different levels of government, community agencies, the business sector, and various individual actors. One significant institution is the Greater Vancouver Regional Steering Committee on Homelessness (RSCH), which brings together over 40 representatives and allocates funding from the federal government to community agencies that work to address homelessness in Metro Vancouver (Basi et al., 2012). Yet the amount of funding allocated by the Greater Vancouver RSCH for services targeting street-involved youth is significantly less than the funding available from the provincial government through the MCFD.

Overall the policies of the MCFD have a dominant role in shaping the service system. This frames the rationale for this article. Through the influence of accreditation on the MCFD (and contracted providers), and the influence of the MCFD on the service system for street-involved youth, it is vital to engender greater understanding of accreditation in order to move forward with effective local planning and intervention.

\section{The MCFD Accreditation Policy}

The policy of British Columbia's provincial MCFD for accreditation of contracted agencies was originally approved in January 1999. Agencies were given five years to adapt to the new requirements. The policy requires third-party accreditation for all service providers with annual Ministry contracts over $\$ 500,000$ (Ministry of Children and Family Development [MCFD], n.d.a). In 2013 there were 18 service providers in Vancouver affected by this requirement (MCFD, 2014). According to the MCFD website, the Ministry assists service providers to pay for the direct costs of accreditation, and may pay for other related costs (MCFD, n.d.a). There are two accreditation bodies approved 
International Journal of Child, Youth and Family Studies (2015) 6(4): 539-560

by the provincial government: The Council on Accreditation (COA) and the Commission on Accreditation of Rehabilitation Facilities (CARF International) (MCFD, n.d.a). Of the accredited agencies listed by the MCFD, approximately $90 \%$ are accredited through CARF International (MCFD, 2013).

As described by the MCFD (n.d.b), the purpose of accreditation is "a process of meeting organizational and program/service standards developed by impartial consumers, stakeholders, professionals, and provincial and national organizations". The key benefits described are the assurance of an appropriate level of organizational proficiency including reliable mechanisms to continually improve quality, as well as numerous management controls to ensure "accountability and efficient, effective use of available resources” (MCFD, n.d.b).

The Commission on Accreditation of Rehabilitation Facilities (CARF International) does not provide free public access to the standards associated with accreditation; however it describes the standards as "developed with the input of providers, consumers, payers, and other experts from around the world" (CARF International 2013a). The Council on Accreditation (COA) provides an overview of its Canadian standards, which are grouped under three broad categories: administration and management, service delivery administration, and service standards (COA, 2013a). According to COA (2013a), standards development is guided by "information gathered formally through expert panels and advisor work groups; informal discussion with human service organizations... and reviews of published research and professional literature”. To examine the accreditation standards or the accrediting institutions in depth is beyond the scope of this paper. The intent is, however, to situate this policy development within broader policy trends, in order to frame the basis for further research into the various aspects of accreditation, as an influential feature of the service system for street-involved youth in Vancouver.

\section{Current Literature on Accreditation in Social/Human Services}

As a general definition, accreditation is "a system and process of reviewing programs against certain quality standards for the purpose of approving (or credentialing) the program” (Brommel, 2006, p. 14). The concept originally emerged in the fields of higher education and medicine in the late 19th century, and did not appear in social and human services until the mid-20th century.

Much of the literature on accreditation focuses on different models and processes of how accreditation works. For example, the Institute of Medicine (2001) proposes three different models of accreditation: supplementary (additional) to government regulation; a substitute for government regulation; or a model whereby standards are developed by one entity (public or private), and the accreditation process is performed by another entity.

There is also a body of literature that looks at the costs and benefits of accreditation. Accreditation has been seen as a valuable tool to assess the value or quality of an organization (Stufflebeam, 2000). More specifically, private (or third party) 
International Journal of Child, Youth and Family Studies (2015) 6(4): 539-560

accreditation has been described as less costly than government oversight, as well as more flexible and responsive to change (Institute of Medicine, 2001). Accreditation also can benefit organizations as a way to "respond to accountability demands" (Lee, McMillen, Knudsen, \& Woods, 2007, p. 52), and a tool for managers to develop performance-monitoring processes (Carman \& Fredericks, 2013). These (or similar) benefits to organizations are described in the limited research on accreditation in the social and human services sector (Slatten, Guidry, \& Austin, 2011; Carman \& Fredericks, 2013).

In terms of critiques, accreditation can be labour/resource intensive and expensive for organizations compared to the value or benefits derived by organizations (Institute of Medicine, 2001; Bowman, as cited in Brommel, 2006, pp. 30-31). Moreover, within the social and human services field, Brommel describes a substantial growth in the number of competing accrediting bodies affiliated with different groups, which can lead to redundancy, misguided priorities, and resistance to change. A significant portion of the research on accreditation in social and human services also looks at the negative effects on front-line workers of imposing practices and priorities that do not reflect their values and reduce their sense of autonomy (Janz, 2004; Bates, 2005; Lirette, 2012).

There is a limited pool of literature on accrediting institutions and much less so in the field of social and human services. Nichols (1980) looked at seven national organizations in the United States that ran accreditation programs in social and human services, and found that the impetus to develop standards came from at least three groups including professional leaders, groups of providers, and external sources such as funders and government (Nichols, 1980, p. 64). The primary focus of Nichols' (1980) study was the way different influences shaped accreditation and standards, highlighting three important trends at that time: "pressure to make accreditation a condition for receipt of funding, a trend away from 'in-house' accrediting, and concern to minimize the cost and maximize the benefits of accrediting programs” (pp. 3-4).

More recently, Brommel (2006) produced a historical analysis of the Council on Accreditation (COA), an accrediting body focused primarily on child, youth, and family services. The purpose of the study was to "examine the context in which COA developed, the assumptions behind its practice...so that social workers and program evaluators may apply the knowledge gained through this research to understand the historical, philosophical, and theoretical basis of accreditation" (Brommel, 2006, p. 9). Along with a thorough description of the evolution of the organization, Brommel found that a primary purpose and ongoing goal of the COA is to promote the social service model of service delivery and program management.

Brommel recommends future research on the organizational capacity of the COA in relation to the stated purpose of the organization, and also recommends research on the value or role of accreditation as a form of program evaluation. Brommel's study also supports the need for further research on accrediting institutions, as she highlights that inherently "power rests not so much with the accredited, but with those who control the process of accreditation” (Malherbe, as cited in Brommel, 2006, p. 32). According to 
International Journal of Child, Youth and Family Studies (2015) 6(4): 539-560

Brommel research on accrediting institutions is foundational to developing a clear theory of accreditation in a given field. However missing from Brommel's (2006) writing, as with the majority of literature on accreditation, is connecting outwards in terms of the role and relationship of accreditation and accrediting institutions to broader social, political, economic, and cultural trends.

Overall, the existing literature on accreditation and accrediting institutions raises several important areas for future research. These include the impact of accreditation on a given service sector, and the congruence of the values of a specific accrediting institution with the values and objectives of an organization or community of service providers. The literature also emphasizes the value of research on specific accrediting institutions, and the relationships between competing institutions, as a means to build a theory of accreditation. In relation to the context of street-youth services in Vancouver, as approximately $90 \%$ of providers contracted by the MCFD use the Commission on Accreditation of Rehabilitation Facilities (CARF International), it would be valuable to produce research on CARF International, to offer a comparative look at Brommel's (2006) study on the Council on Accreditation (COA), which holds only $10 \%$ of the market in British Columbia. However, what is somewhat lacking in the literature on accreditation is perspective on how accreditation fits into the broader evolution of the social and human services sector. Further, based on the limited research on accrediting institutions, the methodology and theoretical framework for such research is underdeveloped. As such, I draw from broader literature on policy trends in public management, as well as transnational private regulation for additional perspective in framing a research agenda on accreditation relevant to the service system for streetinvolved youth in Vancouver.

\section{Policy Trends in Public Management}

As described, the transformation of Vancouver's service system for streetinvolved youth in the late 1990s and early 2000s, specifically in adopting management practices modeled after the business sector, was largely prompted by policy developments at the provincial MCFD. However these developments can also be connected to broader trends in public management. This section will provide a brief overview of such trends, and also draw connections to the recent history of the MCFD.

The movement to bring business practices into British Columbia’s provincial government (including the MCFD) is connected to broader trends in public and nonprofit administration across North America and Western Europe (see Barzelay, 2001). While this "business turn" began to take off in the 1990s, the search for accountability mechanisms and program evaluation was initiated in the early 1970s. This trend is described in part as a reflection of the normative framework of Western democracy, whereby "accountability of government to its constituents is fundamental... and performance measurement and management enable accountability to be determined" (Brunet-Jailly \& Martin, 2010, p. 21). 
International Journal of Child, Youth and Family Studies (2015) 6(4): 539-560

Simultaneously, as demonstrated by numerous scholars, from the 1980s onwards the funding and scope of public welfare services in North America has been in decline (Geiger \& Wolch, 1986; Brodie, 1996; Griffin Cohen, 1997; Harvey, 2005). The overall effect of increasing accountability demands and decreasing resources inserted "markets and market-mimicking devices into the coordination of public services" (Newman \& Clarke, 2009, p. 90). In this way "provider organizations are invited to imagine themselves as a business...to be 'business-like' in the way they manage themselves...identifying and improving the product; mapping competitors and collaborators; assessing the market...capturing and satisfying customers - becomes a framing device for organizational decision-making” (Newman \& Clarke, 2009, pp. 8283).

The recent history of the MCFD mirrors the trends described above in many ways. With regard to accountability and performance evaluation, aside from the accreditation policy for contracted service providers, the MCFD has implemented a range of policies and procedures within the Ministry itself (for a detailed discussion, see Callahan \& Swift, 2007). Further, while Guenther (2011, pp. 73-76) was not able to compare data on MCFD funding for street-youth services over time, she asserts that from the 1990s onwards the overall funding of the MCFD has decreased, while the proportion of MCFD services contracted out has continued to increase (reaching approximately $70 \%$ to $80 \%$ by 2011). Thus key themes identified by Guenther (2011) regarding the MCFD included the "non-profit sector forced into competitiveness" and an increasing "culture of managerialism” (p. 75).

The literature highlighted above raises several important critiques that can be related to accreditation, and contribute to the formulation of a research agenda. A first concern is that tools and policies related to monitoring and evaluation often simultaneously move towards standardization, and represent an assumption that standardization is equated with quality. According to Callahan and Swift (2007, p. 171), while some degree of standardization is considered desirable within the field of social work, flexibility is also considered vital to the autonomy and effectiveness of front-line staff, at the risk of an overly prescriptive service system with a "one-size-fits-all" approach. These are thoughts echoed elsewhere in the literature on management in public service professions, wherein research suggests that positive outcomes in actuality correlate with the capacity of different professional groups to practice discretion and autonomy by renegotiating policy implementation either formally or informally (Brodkin, 2011; McCann \& Ward, 2011; Miller, 2005).

Another concern is that performance measurement and program evaluation often "measures what they can count... rather than what counts" (Brunet-Jailly \& Martin, 2010, p. 22). This concern is amplified by Brodkin's (2011) research; she describes the management prerogative: "as long as performance benchmarks are met, it is not necessary to consider how policy work is done” (p. 272). Yet, similar to Callahan and Swift (2007), the results of her research demonstrate that while overall benchmarks may be met, the underlying and unacknowledged impacts could include the shifting of 
International Journal of Child, Youth and Family Studies (2015) 6(4): 539-560

administrative costs onto clients, prioritizing "speed over need", and creating restrictions on access to services (Brodkin, 2011, p. 273).

A third concern related to performance measurement and program evaluation practices, is that "what counts" is assumed to be obvious and apolitical. However as described by Agocs and Brunet-Jailly (2010), measurement is inherently political, occurs within a context of power relations, and is influenced by dominant values and ideologies. As a certain degree of standardization, as well as a focus on performance and program evaluation is inherent in accreditation, these concerns demonstrate the need for both indepth research on accreditation and standards, and a contextual view of the broader social, political, and economic trends that have shaped their development and implementation.

\section{Private Transnational Regulatory Standards Institutions}

Based on a review of the literature, I propose that both accrediting institutions approved in British Columbia (the COA and CARF International) can be considered "private transnational regulatory standards institutions", a perspective that offers important insight to framing research on accreditation. Each of these terms has specific significance in describing the characteristics of the accreditation bodies. In order to explore these ideas further, I draw from literature on transnational private regulation (TPR), the theory of regulatory capitalism, and select literature related to regulation, standards, and "novel assemblages" of governance.

Both COA and CARF International are based in the United States yet perform accreditation in Canada, amongst other countries. Further, their accreditation has been incorporated into government policies and legislation through "mandated" or "deemed" status in numerous states and provinces. Therefore according to the literature on TPR, these institutions are transnational as "their effects cross borders, but are not constituted through the cooperation of states as reflected in treaties” (Scott, Cafaggi, \& Senden, 2011, p. 3).

These accreditation bodies are also private, as they are independent not-for-profit organizations governed by a Board of Directors. Based on their function in setting industry standards, the COA and CARF International fit the definition of regulatory standards institutions, which "set and enforce standards for performance" (Bartley, 2007, p. 302). These standards, which represent a set of agreed-upon rules and norms related to the technical or other qualities of any system of production (Salter \& Salter, 1997), are regulated through some form of "implementation and enforcement...legal or non-legal" (Black, 2008, p. 139); for an expanded discussion on standards see Salter (1994). Institutions - as situated within the literature on TPR - are a central component of "governance regimes which take the form of 'coalitions of non-state actors which codify, monitor, and in some cases certify firms' compliance with labor, environmental, human rights, or other standards of accountability” (Barley, as cited in Scott et al., 2011, p. 3). 
International Journal of Child, Youth and Family Studies (2015) 6(4): 539-560

Lipshutz and Fogel (2002) point out that regulation is a fundamental feature of contemporary governance:

While participation in international public affairs by socially based, nonstate actors is not new, it appears that the current scope of non-profit, nongovernmental activity at all political levels far exceeds that found in the historical record. Not only have social actors become more involved in many international meetings and institutions, and in transnational networks and alliances of various types; they have also become instrumental in the establishment of a growing number of semi-public and private transnational regimes. (pp. 116-117)

This shift in regulatory responsibility has historically been seen as part of broader trends in welfare state reform, notably propelled forward by the Reagan Administration and the Thatcher Government of the 1980s (see Peck \& Tickell, 2002), whereby what had previously been considered core government functions (including welfare provision and regulation) were shifted to an array of non-state actors (Black, 2008). Yet in this way, regulation is conceived primarily as a responsibility shifted to the private sector, as opposed to a core mechanism of governance itself. Levi-Faur (2005) describes the trend:

the notion of a new order of regulatory capitalism goes beyond privatization and includes an increase in delegation to autonomous agencies, formalization of relationships, proliferation of new technologies of regulation in both public and private spheres, and the creation of new layers of both national and international regulation. (p. 202)

While aspects of regulatory capitalist theory have been challenged, and much debate exists regarding how much the responsibilities and functions of the state have been transferred to private actors - that is, is the state a rule "maker" or a rule "taker" (Cafaggi, 2011, p. 21)? - it is clear that the reallocation of regulatory power has important implications with regard to both governance and accountability.

Cafaggi (2011) argues that the recent growth of private regulatory institutions reflects "first, a reallocation of regulatory power from the domestic to global sphere and second, a redistribution between public and private regulators” (p. 21). These are two important yet distinct features in considering the place of regulatory institutions on governance. I will begin with a discussion of the second feature, the division of control between state and non-state actors, and then move to the first feature, that of scale.

According to Brunet-Jailly and Martin (2010), the shift in public policy discourse from a focus on the formal structures and institutions of government to the wider frame of "governance" demonstrates a recognition of the various processes through which nonstate actors participate in decision-making, wield power and authority, and in turn influence public policy (see also Young, 2012). The literature on regulatory capitalism suggests that through the emergence of regulatory regimes, a new form of "second-level indirect representative democracy” is taking shape, whereby "citizens elect 
International Journal of Child, Youth and Family Studies (2015) 6(4): 539-560

representatives who control and supervise experts who formulate and administer policies" (Levi-Faur, 2005, p. 201).

While these changes are often considered a form of privatization, whereby the process of regulation has been "captured" to varying degrees by private actors (e.g., Mattli \& Woods, 2009), this overlooks a key detail related to the topic of governance. Not only is there a shift in authority between "public" and "private" but also the very notion of what is "public" should be reconsidered. The conventional notion of the state under liberal democracy has taken new form. This transformation is described by Salter and Salter (1997) as a newly emerging infrastructure, and by Sassen (2008) as a movement away from the very idea of the nation state as the "center" of a clearly structured governance network. As illustrated by Sassen (2008), "specialized assemblages” form that spread and disperse control, cross traditional notions of borders and boundaries, and are linked based more on sector or interest than territory (p. 61). These ideas challenge the fundamental frameworks through which "modern societies, economies and polities have operated" (p. 61), as the structure of governance has changed, and with it the lines between public and private have blurred.

This development relates directly to the other aspect of redistribution of regulatory power: the shift from the domestic to the global sphere. As highlighted by Lipschutz and Fogel (2002), while globalization receives much attention for its disruptive social and economic effects, the topic of regulation is often not considered. As noted above, a key feature of the current period is the multiplication of different, highlyspecialized governance "assemblages" defined more through interest or industry versus traditional territorial boundaries (Sassen, 2008, p. 61). In this regard, McCann and Ward (2013) suggest it is useful to think of the varying levels of political organization as nonstatic, and to "focus on how [these varying] scales are brought and held together assembled - by actors and institutions” (p. 5). Overall, they argue we have moved beyond "easy analytical dichotomies" of local/global and public/private, and must look to the practices and actors/institutions that are networked together in fluid governance arrangements (p. xvi).

With regard to the accreditation bodies COA and CARF International, these institutions are embedded within broader regulatory regimes or so-called governance “assemblages”. Accreditation by different institutions has become incorporated into government policies or regulation in various territorial settings. However this is also fluid, as these "mandates" by the states and provinces often change. Therefore the accrediting institutions in some ways assemble their own governance regimes that not only span traditional borders, but are also incorporated into broader regulatory regimes that included different accrediting bodies, are held together and expanded by a range of actors/institutions, and are connected to diverse and possibly conflicting social, economic, and political projects. 
International Journal of Child, Youth and Family Studies (2015) 6(4): 539-560

\section{Informing a Future Research Agenda}

Based on the literature review on accreditation, policy trends in public management, and private transnational regulatory standards institutions, several important theoretical and methodological considerations emerge, as well as important points for future investigation.

In formulating a plan for future research it is essential to return to the underlying objective of this paper, namely, to produce key points of inquiry to build a better understanding of the relationship between private accreditation and the service system for street-involved youth in Vancouver, Canada. To do so, as outlined below, it is necessary to focus on the standards and accrediting institutions directly connected to this context, and also to look to the broader context of accreditation, as it is embedded within broader regulatory regimes and governance assemblages, as well as social, political, economic, and cultural processes.

Future research is needed on the value and impact of accreditation on services, staff, and organizations, as well as the congruity (or not) of the culture and objectives of accrediting standards and those of the local community of service providers, policymakers, and the general population. The issue of the added cost of accreditation - both in terms of the fees as well as the significant administrative resources required - is identified as a significant factor in determining whether (and what type) of organizations can achieve and maintain accreditation.

Further, research on accrediting institutions is described as a valuable tool to develop a broader theory of accreditation in social and human services, and is necessary given that a power imbalance exists that favors those who control accreditation over "the accredited” (Malherbe, as cited in Brommel, 2006, p. 32). This body of literature highlights an important issue around the growth in competing accreditation bodies, and how this shapes the practices and objectives of the different accrediting bodies. Lastly, research that could allow for a comparative look at competing accrediting institutions would provide important insight into the different characteristics of the institutions and their standards, as well as how or why they "fit" with different local settings. Since CARF International holds $90 \%$ of the market in British Columbia versus the $10 \%$ market share of the COA, a better understanding of these accrediting bodies could provide valuable insights into the service providers and the overall service system for streetinvolved youth.

In looking at the connections between the street-involved youth services in Vancouver, the policies of the MCFD, and the literature on policy trends in public management, several important themes emerge that merit further inquiry in relation to the specific context of Vancouver's street youth services. First, it should be recognized that accreditation plays a substantial role in the "competitive market" between service providers, and thus the relationship between the MCFD accreditation policy and the landscape of service providers for street-involved youth should be explored in greater depth. Second, as identified within the literature, a risk of the emphasis on meeting 
performance benchmarks, specifically within a highly competitive environment for funding, is that the pressure to meet such benchmarks may trump other more nuanced aspects of service delivery that are not easy to measure. A third related theme involves implicit assumptions that surround policies that aim to standardize, improve efficiency, or implement so-called best practices. As noted by multiple scholars, while such initiatives are generally framed as technical and thus apolitical, overarching values, ideologies, and power dynamics inherently shape them. Therefore a critical look at the political and cultural implications of accreditation is necessary.

Through the literature review on transnational private regulatory standards institutions, it is clear that accreditation institutions are a component of broader regulatory regimes with highly complex and fluid characteristics. As such, there is an ambiguity of responsibility and control in accreditation, and by proxy local service systems. This body of literature is rich in methodology and, therefore, I've identified four broad approaches outlined within the literature that I believe would be useful in framing future research on accreditation in social and health services.

The first approach is to focus on specific institutions, such as the Council on Accreditation (COA) or the Commission on Accreditation of Rehabilitation Facilities (CARF International), which can provide an in-depth perspective on the various relationships, interests, and power dynamics involved in decision-making processes. Salter (1998) describes standard setting as "the housework of capitalism”, whereby regulatory institutions represent "the detailed implementation of both policy and politics" (p. 163, emphasis added). In this regard, Salter (2013) makes a case for the added insight that can be gained from specificity, as compared to a broader analysis: "In studying actors, you focus on those individuals, groups, organizations, governmental units and corporate bodies that do things to affect the fate of public issues; in studying institutions, you focus on the constraints operating on these same actors...to the systemic influences on deliberation and decision-making” (p. 3).

More specifically, several scholars advocate in favor of a close examination of the origin of regulatory institutions, as a way to explore how the conditions of emergence relate to the practices and effects of regulation over time (see Scott et al., 2011). Bartley (2007) points out that "institutions arise out of political, cultural, or professional projects led by strategically positioned and socially skilled 'institutional entrepreneurs"” (p. 309). In this way private regulation is - at least to some extent - a manifestation of the interests of those advancing the regime, an important perspective to consider in regard to private regulation in the form of agency accreditation. The actors involved, in all likelihood, have "different, and often conflicting incentives for creation and implementation” (Cafaggi, 2011, p. 31), depending upon their relationship to the service system. While the objective of improving quality may well be present, when the social or human services operate in a competitive market, actors are inherently responding to different "incentives, risks, and uncertainties in the market” (Bartley, 2007, p. 306). For this reason, a comprehensive look at the emergence and development of a regulatory institution can offer a snapshot of the social, political, and economic dynamics at play, which can then be related to a specific context, such as the street-youth service system in Vancouver. 
International Journal of Child, Youth and Family Studies (2015) 6(4): 539-560

Both the second and third approaches to research expand out from the individual regulatory bodies in order to consider the multitude of other actors and institutions that make up the broader regulatory regime. A regulatory regime includes "not only the regulator and the regulated but also the beneficiaries of the regulatory process" (Cafaggi, 2011, p. 32). The primary difference between the two approaches is based on scale. On one hand, a regulatory regime can be considered primarily within a localized context, such as a city or urban region. On the other, the regime can be considered on a much broader scale wherein the territorial boundaries of a regime are fluid.

The work of McCann and Ward (2011) on urban policy mobilities provides a strong framework for researching a regulatory regime centered around a city or urban region. Their mode of inquiry focuses on particular case studies using "ethnography or careful technical analysis, but does not lose sight of the contexts and constraints within which these practices are located" (p. xvii). This approach looks at "how policies are carried from place to place and learned in specific setting” (McCann, 2010, p. 107), as well as the relationships and actors of the specific research site (city). This provides direct insight into both of the themes identified above - the values, ideologies, and competing interests at play - as well as the dynamics of power and control.

A key feature of accreditation and policy-making processes in general is the prominent role of private actors with technical knowledge or expertise. As described by McCann and Ward (2011), “the expertise of various think tanks, consultants, gurus, and mediators has become central to day-to-day governance [of local settings]... and these actors act as key agents in the transference of policies and practices in urban governance" (p. xix). Cutler (2010) agues that similar to the depoliticized framing of performance metrics, "the particularistic interests pursued by experts are obscured by presumptions of the technical and neutral nature of their professional knowledge", and thus "few question just whose interests these private actors represent” (p. 160). To this regard, the methodological approach of McCann and Ward's work allows for a critical look at the interests of various actors, as well as the relationships and hierarchy between them.

The third research approach looks at a regulatory regime as an expansive network that crosses territorial boundaries. The work in this area focuses on the relationships between actors, as a means to explore the varying competing/complementary interests involved. At the same time, this body of work looks at regulatory regimes to explore the emerging phenomenon of cross-border governance networks.

The methodology proposed by Cafaggi (2011) attempts to classify the relationship between actors, to identify dominant actors within the regime, and specifically to look at the degree of complementary interests between actors (see pp. 32-35 for a detailed account). Cafaggi then seeks to use this information to analyze boundaries, such as between public and private, as well as local, national, and transnational. In the same vein, Black (2008) proposes a "decentering” analysis of regulation. This approach examines the "institutional embeddedness" of regulatory regimes within the broader social environment, an approach conceptually rooted in structuration theory whereby 
International Journal of Child, Youth and Family Studies (2015) 6(4): 539-560

"regulation, like any set of social relations, is dialectical: both regulator and regulated are at once autonomous and dependent on each other” (p. 140). In this way her research looks at private regulation as a proxy to explore the nature of how legitimacy and accountability are socially defined.

The final approach to this topic is a look at the accreditation standards themselves, and the impact of the standards on service delivery practices, service providers, and the outcomes resulting from the implementation of the standards. While this approach would also provide insight into values, ideologies, and competing interests involved in accreditation, as well as to a certain degree the power dynamics surrounding regulation in the service system, this area is less of a focus in the literature surrounding transnational private regulatory standards institutions. At the same time, this is an important area to consider in regard to informing planning and policy-making to address youth homelessness. Future research in this area could draw on institutional ethnography methodology (Smith, 2005) as a means to further explore the relationship between institutional practices and the experiences of service providers and service users.

Overall, based on the above literature review, an expansive future research agenda is revealed, as the gap in knowledge related to private accreditation in the social/human services sector spans from a micro-level of service providers and the local regulatory regimes that form around urban centers, to a level of transnational accreditation bodies and the broader regime in which they are embedded.

\section{Conclusion}

In British Columbia accreditation requirements for contracted service providers are an outgrowth of a progressive policy trend in the public sector, towards greater standardization and performance measurement. While in some ways accreditation is still optional for street-youth service providers in Vancouver, it is a necessary condition to access funding from the MCFD, which is the most significant funder of service providers. As described by Cafaggi (2011), "compliance with a set of standards conditions access to the market or the ability to compete, thereby reducing freedom to choose” (p. 22).

Through this paper, I propose an expanded perspective of the service system for street-involved youth in Vancouver to include a broader look at the actors, institutional arrangements, and influences involved in governance and policy-making. I also challenge dominant assumptions about the apolitical nature of accreditation, and argue for a more nuanced and inquisitive look at accreditation and accrediting institutions/regimes. In pursuing the proposed research agenda I believe that policy research and advocacy can be strengthened, in order to support the broader objective of ending youth homelessness in Vancouver and beyond. 
International Journal of Child, Youth and Family Studies (2015) 6(4): 539-560

\section{References}

Agocs, C., \& Brunet-Jailly, E. (2010). Performance management in Canadian local government: A journey in progress or a dead deal? In E. Brunet-Jailly \& J. Martin (Eds.), Local government in a global world: Australia and Canada in comparative perspective (pp. 154-178). Toronto: University of Toronto Press Incorporated.

Bartley, T. (2007). Institutional emergence in an era of globalization: The rise of transnational private regulation of labor and environmental conditions. American Journal of Sociology, 113(2), 297-351. http://dx.doi.org/10.1086/518871

Barzelay, M. (2001). The new public management: Improving research and policy dialogue. Berkeley: University of California Press.

Basi, S., Clelland, T., Khind, N., Morris, A., \& Severinson, P. (2012). Housing homeless youth in Vancouver: Key barriers and strategic responses. Toronto: York University. Retrieved from http://www.homelesshub.ca/Library/HousingHomeless-Youth-in-Vancouver-Key-Barriers-and-Strategic-Responses54368.aspx

Bates, R. M. (2005). Reframing the 'A' word: Front line worker perceptions of organizational change and personal transitions through the process of child and family services accreditation (master's thesis). University of Victoria, Victoria, BC. Retrieved from ProQuest.

Black, J. (2008). Constructing and contesting legitimacy and accountability in polycentric regulatory regimes. Regulation \& Governance, 2(2), 137-164. http://dx.doi.org/10.1111/j.1748-5991.2008.00034.x

Brodie, J. (1996). Restructuring and the new citizenship. In I. Bakker (Ed.), Rethinking restructuring: Gender and change in Canada (pp. 126-140). Toronto: University of Toronto Press.

Brodkin, E. (2011). Policy work: Street-level organizations under new managerialism. Journal of Public Administration Research and Theory, 21(Supplement 2), 257277. http://dx.doi.org/10.1093/jopart/muq093

Brommel, S. M. (2006). A historical analysis: The council on accreditation for children and family services (Doctoral dissertation). Retrieved from Proquest. (UMI Number: 3230153).

Brunet-Jailly, E., \& Martin, J. (2010). Local government in a global world: Australia and Canada in comparative perspective. In E. Brunet-Jailly \& J. Martin (Eds.), Local government in a global world: Australia and Canada in comparative perspective (pp. 3-34). Toronto, Canada: University of Toronto Press Incorporated. 
International Journal of Child, Youth and Family Studies (2015) 6(4): 539-560

Cafaggi, F. (2011). New foundations of transnational private regulation. Journal of Law and Society, 38(1), 20-49. http://dx.doi.org/10.1111/j.1467-6478.2011.00533.x

Callahan, M., \& Swift, K. (2007). Great expectations and unintended consequences: Risk assessment in child welfare in British Columbia. In L. Foster \& B. Wharf (Eds.), People, politics, and child welfare in British Columbia (pp. 158-183). Vancouver, BC: UBC Press.

Carman, J., \& Fredericks, K. (2013). Nonprofits and accreditation: Exploring the implications for accountability. International Review of Public Administration, 18(3), 51-68. http://dx.doi.org/10.1080/12294659.2013.10805263

Commission on Accreditation of Rehabilitation Facilities (CARF International). (2013a). Quality standards. Retrieved from http://www.carf.org/Accreditation/QualityStandards/

Commission on Accreditation of Rehabilitation Facilities (CARF International). (2013b). Who we are. Retrieved from http://www.carf.org/About/WhoWeAre/

Commission on Accreditation of Rehabilitation Facilities (CARF International). (2013c). Value of accreditation. Retrieved from http://www.carf.org/Accreditation/ValueofAccreditation/

Concodora, S. (2008). Serving youth through systems integration. Children's Voice, 17(4), 14-17.

Council on Accreditation (COA). (2013a). Canadian standards. Retrieved from http://coanet.org/standards/standards-for-canadian-organisations/

Council on Accreditation (COA). (2013b). About COA. Retrieved from http://coanet.org/about/about-coa/

Cutler, C. (2010). The legitimacy of private transnational governance: Experts and the transnational market for force. Socio-Economic Review, 8(1), 157-185. http://dx.doi.org/10.1093/ser/mwp027

De Jong, I. (2013, September 2). Your organization's identity crisis. Retrieved from http://www.orgcode.com/2013/09/02/your-organizations-identity-crisis/

Gaetz, S. (2009). Backgrounder: “Who are street youth?”. Toronto, Canada: Homeless Hub. Retrieved from: http://www.homelesshub.ca/Library/Who-are-Street-Youth46117.aspx

Gaetz, S. (2014). Coming of age: Reimagining the response to youth homelessness in Canada. Toronto: Canadian Homelessness Research Network. 
International Journal of Child, Youth and Family Studies (2015) 6(4): 539-560

Gaetz, S., O’Grady, B., Buccieri, K., Krabanow, J., \& Marsolais, A. (2013). Introduction. In S. Gaetz, B. O’Grady, K. Buccieri, J. Krabanow, \& A. Marsolais (Eds.), Youth homelessness in Canada: Implications for policy and practice (pp. 1-14). Toronto: Canadian Homelessness Research Network Press.

Geiger, R., \& Wolch, J. (1986). A shadow state? Voluntarism in metropolitan Los Angeles. Environment and Planning D: Society and Space, 4(3), 351-366. http://dx.doi.org/10.1068/d040351

Greater Vancouver Regional Steering Committee on Homelessness. (2003). Regional homelessness plan for Greater Vancouver. Vancouver, BC: Social Planning and Research Council of BC. Retrieved from: http://stophomelessness.ca/wpcontent/uploads/2008/09/Regional-Homelessness-Plan-2003.pdf

Griffin Cohen, M. (1997). From the welfare state to vampire capitalism. In P. Evans \& G. Wekerle (Eds.), Women and the Canadian welfare state: Challenges and change (pp. 28-70). Toronto: University of Toronto Press.

Guenther, D. (2011). How have neoliberal shifts from the 1980s to present day in social welfare delivery changed the services provided to street youth in Vancouver? (Unpublished doctoral thesis). Simon Fraser University, Burnaby, BC, Canada.

Hambrick, R., \& Rog, D. (2000). The pursuit of coordination: The organizational dimension in the response to homelessness. Policy Studies Journal, 28(2), 353364. http://dx.doi.org/10.1111/j.1541-0072.2000.tb02035.x

Harvey, D. (2005). A brief history of neoliberalism. New York: Oxford University Press.

Institute of Medicine. (2001). Preserving public trust: Accreditation and human research participant protection programs. Washington, DC: National Academy Press.

Janz, S. L. (2004). Accreditation and government contracted social service delivery in British Columbia: A reorganization of frontline social service work (Unpublished master's thesis). University of Victoria, Victoria, BC.

Lee, B., McMillen, J., Knudsen, K., \& Woods, C. (2007). Quality-directed activities and barriers to quality in social service organizations. Administration in Social Work, 31(2), 67-85. http://dx.doi.org/10.1300/j147v31n02_05

Levi-Faur, D. (2005). The global diffusion of regulatory capitalism. In D. Levi-Faur \& J. Jordana (Eds.), The rise of regulatory capitalism: The global diffusion of a new order. The ANNALS of the American Academy of Political and Social Science, 598, 200-203.

Lindell, J. R. (2012). Educating at-risk students in alternative settings: Students' perspectives. Dissertation Abstracts International Section A: Humanities and Social Sciences, 73(2-A). Retrieved from Proquest. (UMI Number: 3481543). 
International Journal of Child, Youth and Family Studies (2015) 6(4): 539-560

Lipschutz, R., \& Fogel, C. (2002). “Regulation for the rest of us?” Global civil society and the privatization of transnational regulation. In R. B. Hall \& T. Biersteker (Eds.), The emergence of private authority in global governance (pp. 115-140). Cambridge, UK: Cambridge University Press. http://dx.doi.org/10.1017/cbo9780511491238.007

Lirette, P. R. (2012). Child care accreditation in Alberta: An institutional ethnography (Unpublished master's thesis). University of Alberta, Edmonton, AB.

Madison, A. (2000). Language in defining social problems and in evaluating social programs. New Directions for Evaluation, 86, 17-28. http://dx.doi.org/10.1002/ev.1169

Mattli, W., \& Woods, N. (2009). In whose benefit? Explaining regulatory change in global politics. In W. Mattli \& N. Woods (Eds.), The politics of global regulation (pp. 1-43). Princeton, NJ: Princeton University Press. http://dx.doi.org/10.1515/9781400830732.1

McCann, E. (2010). Urban policy mobilities and global circuits of knowledge: Toward a research agenda. Annals of the Association of American Geographers, 101(1), 107-130. http://dx.doi.org/10.1080/00045608.2010.520219

McCann, E., \& Ward, K. (2011). Introduction. Urban assemblages: Territories, relations, practices, and power. In E. McCann \& K. Ward (Eds.), Mobile urbanism: Cities and policymaking in the global age (pp. xviii-xxxv). Minneapolis, MN: University of Minnesota Press.

McCann, E., \& Ward, K. (2013). A multidisciplinary approach to policy transfer research: Geographies, assemblages, mobilities and mutations. Policy Studies, 34(1), 2-18. http://dx.doi.org/10.1080/01442872.2012.748563

Millar, H. (2009). Rehousing Vancouver's street-involved youth [CPRN research report]. Vancouver, BC: Canadian Policy Research Networks Inc.

Miller, C. (1998). Canadian non-profits in crisis: The need for reform. Social Policy \& Administration, 32(4), 401-419. http://dx.doi.org/10.1111/1467-9515.00123

Miller, C. (2005). Book review: The new managerialism and public service professions. The British Journal of Social Work, 35(5), 772-774. http://dx.doi.org/10.1093/bjsw/bch312

Ministry of Children and Family Development (MCFD). (n.d.-a). Accreditation of contractors. Victoria: Government of British Columbia. Retrieved from http://www.mcf.gov.bc.ca/accreditation/contractors.htm

Ministry of Children and Family Development (MCFD). (n.d.-b). Purpose and benefits. Victoria: Government of British Columbia. Retrieved from http://www.mcf.gov.bc.ca/accreditation/purpose.htm 
International Journal of Child, Youth and Family Studies (2015) 6(4): 539-560

Ministry of Children and Family Development (MCFD). (2013, October). Accredited agencies. Victoria: Government of British Columbia. Retrieved from: http://www.mcf.gov.bc.ca/accreditation/pdf/acc_agencies.pdf

Ministry of Children and Family Development (MCFD). (2014, October). Accredited agencies. Victoria: Government of British Columbia. Retrieved from: http://www.mcf.gov.bc.ca/accreditation/pdf/acc_agencies.pdf

Newman, J., \& Clark, J. (2009). Publics, politics \& power. Thousand Oaks, CA: SAGE Publications. http://dx.doi.org/10.4135/9781446216651

Nichols, A. (1980). Accreditation in the field of social welfare: An approach to selfregulation and social control (Unpublished doctoral dissertation). Columbia University, New York.

Peck, J., \& Tickell, A. (2002). Neoliberalizing space. In N. Brenner \& N. Theodore (Eds.), Spaces of neoliberalism: Urban restructuring in North America and western Europe (pp. 33-57). Oxford: Blackwell. http://dx.doi.org/10.1002/9781444397499.ch2

Rosenheck, R., Morrissey, J., Lam, J., Calloway, M., Stolar, M., Johnsen, M., et al. (2001). Service delivery and community: Social capital, service systems integration, and outcomes among homeless persons with severe mental illness. Health Services Research, 36(4), 691-710.

Salter, L. (1994). The housework of capitalism: Standardization in the communications and information technology sectors. International Journal of Political Economy, 23(4), 105-133. http://dx.doi.org/10.1080/08911916.1993.11643871

Salter, L. (1998). Reply to Goodman's comment on “The new infrastructure”. Studies in Political Economy, 57, 163-165.

Salter, L. (2013). Rules of the game: Institutions as determinants of decisions about public issues. Understanding Decisions that Matter. Manuscript submitted for publication.

Salter, L., \& Salter, R. (1997). The new infrastructure. Studies in Political Economy, 53, 67-102.

Sassen, S. (2008). Neither global nor national: Novel assemblages of territory, authority and rights. Ethics \& Global Politics, 1(1-2), 61-79. http://dx.doi.org/10.3402/egp.v1i1.1814

Scott, C., Cafaggi, F., \& Senden, L. (2011). The conceptual and constitutional challenge of transnational private regulation. Journal of Law and Society, 38(1), 1-19. http://dx.doi.org/10.1111/j.1467-6478.2011.00532.x 
International Journal of Child, Youth and Family Studies (2015) 6(4): 539-560

Skinner, M., \& Rosenberg, M. (2005). Co-opting voluntarism? Exploring the implications of long-term care reform for the nonprofit sector in Ontario. Environment and Planning C: Government and Policy, 23, 101-121. http://dx.doi.org/10.1068/c0434

Slatten, L., Guidry, B., \& Austin, W. (2011). Accreditation and certification in the nonprofit sector: Organizational and economic implications. Organizational Management Journal, 8(2), 112-127. http://dx.doi.org/10.1057/omj.2011.17

Smith, D. (2005). Institutional ethnography: A sociology for people. Oxford, UK: AltaMira Press.

Social Planning and Research Council of Hamilton. (2009). Building collaboration between the child welfare and street-involved youth services sectors in Hamilton. Hamilton, ON: P. McNaney. Retrieved from: http://www.homelesshub.ca/Library/Building-Collaboration-Between-the-ChildWelfare-and-Street-Involved-Youth-Services-Sectors-in-Hamilton-51106.aspx

Stufflebeam, D. L. (2000). Foundational models for $21^{\text {st }}$ century program evaluation. In. D. L. Stufflebeam, G. Madaus, \& T. Kellaghan (Eds.) Evaluation models: Viewpoints on educational and human services evaluation. Boston: Kluwer Academic Publishers.

Toro, P., Lesperance, T., \& Braciszewski, J. (2011). The heterogeneity of homeless youth in America: Examining typologies. Washington, DC: Homelessness Research Institute. Retrieved from http://onefamilyinc.files.wordpress.com/2011/10/homeless_youth_in_america.pdf

Wiig, J., \& Tuell, J. (2008). Guidebook for juvenile justice \& child welfare system coordination and integration: A framework for improved outcomes. Arlington, VA: Child Welfare League of America, Inc.

Young, R. (2012). Introduction: Multilevel governance and its central research questions in Canadian cities. In M. Horak \& R. Young (Eds.), Sites of governance: Multilevel governance and policy making in Canada's big cities (pp. 3-25). Montreal: McGill University Press. 